\title{
Speciation of Phosphorus in a Fertilized, Reduced-Till Soil System: In-Field Treatment Incubation Study
}

\author{
Raju Khatiwada \\ Ganga M. Hettiarachchi* \\ David B. Mengel \\ Dep. of Agronomy \\ Throckmorton Plant Sciences Center \\ Kansas State Univ. \\ Manhattan KS 66506

\section{Mingwei Fei} \\ Dep. of Statistics \\ Dickens Hall \\ Kansas State Univ. \\ Manhattan KS 66506
}

Phosphorus management in reduced-tillage systems is a great concern for farmers. Conclusive positive results of deep-banding $\mathbf{P}$ fertilizers compared with broadcast application and the chemistry of reduced-tillage systems remain unclear. Knowledge of the dominant solid $P$ species present in soil following application of $\mathbf{P}$ fertilizers and the resulting potential $\mathbf{P}$ availability would help us understand and efficiently manage $P$ in reducedtillage systems. The objective of this research was to study the influence of placement (broadcast vs. deep-band P), fertilizer source (granular vs. liquid $P$ ), and time on the reaction products of $\mathbf{P}$ under field conditions. Changes in soil $\mathrm{pH}$, resin-extractable $\mathrm{P}$, total $\mathrm{P}$, and speciation of $\mathrm{P}$ were determined at different distances from the point of fertilizer application at $5 \mathrm{wk}$ and 6 mo after $P$ application at a rate of $75 \mathrm{~kg} \mathrm{ha}^{-1}$ to a soil system that was under long-term reduced tillage. Resin-extractable $\mathbf{P}$ was lower for broadcast treatments compared with deep-band treatments for both time periods. Resin-extractable $\mathbf{P}$ was greater in the liquid P-treated soils than in the granular P-treated soils. Speciation results showed that granular $\mathbf{P}$ fertilizers tended to form Fe-P-like forms, whereas liquid forms remained in adsorbed P-like forms in the soil $5 \mathrm{wk}$ after application; moreover, speciation results showed granular $\mathbf{P}$ fertilizers precipitated less when deep-banded. During the 6-mo period following application, reaction products of broadcast granular, broadcast liquid, and deep-band granular fertilizers transformed to Ca-phosphate or mixtures of $\mathrm{Ca}-$, Fe- and adsorbed-phosphate-like forms, whereas deep-band liquid P remained as mainly adsorbed P-like forms. Deepbanding of $\mathbf{P}$ would most likely provide a solution that is both agronomically and environmentally efficient for reduced-till farmers.

Abbreviations: LC, linear combination; MAP, monoammonium phosphate; PCA, principal component analysis; XANES, X-ray absorption near edge structure.

$\mathrm{P}$ hosphorus is an essential element for all life forms, but it is one of the most difficult nutrients for plants to obtain from the soil, so it often represents a limiting factor to agricultural production. Although $\mathrm{P}$ is needed in adequate quantities for optimal crop production, it also has been associated with eutrophication of surface water bodies (Pierzynski et al., 2000). In general, more total $\mathrm{P}$ creates more environmental concern. Millions of tonnes of $\mathrm{P}$ are applied to soil annually, but plants do not have access to all of it. In time, part of the applied $\mathrm{P}$ is taken up by plants, but the majority of $\mathrm{P}$ reacts with other soil components, thus altering $\mathrm{P}$ availability by forming insoluble secondary $\mathrm{P}$ minerals that are precipitated, strongly sorbed onto mineral or organic surfaces (Hansen et al., 2002), or incorporated into soil organic fraction (Fixen and Ludwick, 1982). The fraction of soil $\mathrm{P}$ that is bonded to the surface of soil solids where a discrete mineral phase is not formed is known as adsorbed P (Foth and Ellis, 1997). Phosphorus

Soil Sci. Soc. Am. J. 76:2006-2018

doi:10.2136/sssaj2011.0299

Contribution no. 12-066-J from the Kansas Agric. Exp. Stn.

Received 29 Aug. 2011.

*Corresponding author (ganga@ksu.edu).

(C) Soil Science Society of America, 5585 Guilford Rd., Madison WI 53711 USA

All rights reserved. No part of this periodical may be reproduced or transmitted in any form or by

any means, electronic or mechanical, including photocopying, recording, or any information storage and retrieval system, without permission in writing from the publisher. Permission for printing and for reprinting the material contained herein has been obtained by the publisher. 
is found adsorbed on the surfaces of clay, amorphous $\mathrm{Al}$ or $\mathrm{Fe}$ oxides in acid soils, and calcium carbonate in alkaline soils. The majority of adsorbed $\mathrm{P}$ in soil occurs as inner-sphere complex species (specific adsorption), and some $\mathrm{P}$ is adsorbed as either diffuse ion swarm or outer-sphere complex species (nonspecific adsorption) (Sposito, 1989). Inner-sphere complexed P is slower to equilibrate with the soil solution $\mathrm{P}$ than outer sphere and diffuse swarm $P$.

Hedley and McLaughlin (2005) reviewed the reactions that occur when a highly water-soluble fertilizer granule is placed in soil. The first reaction is wetting of the granule, which occurs through capillary flow of water from soil into the porous granule and through water vapor transfer from the soil or atmosphere to the hygroscopic phosphate salt (Lawton and Vomocil, 1954). This movement of water occurs in a direction opposite that of dissolved $\mathrm{P}$ diffusion, and hence may slow or restrict the diffusion of $\mathrm{P}$, thus increasing the chances for $\mathrm{P}$ fixation due to precipitation reactions. In the case of liquid P fertilizers, this effect is not as great as in the granular P fertilizers due to the amount of water added with liquid P (Hettiarachchi et al., 2006). As $\mathrm{P}$ fertilizer granules dissolve, $\mathrm{P}$ moves out of the granule and forms two reaction zones in the adjacent soil: a P-saturated zone immediately adjacent to the granule in which the $\mathrm{P}$ sorption capacity of the soil is exceeded and precipitates of $\mathrm{P}$ form with the metal ions and organic matter released from the soil due to low $\mathrm{pH}$ and high salt concentrations, and a P-unsaturated zone in which the $\mathrm{P}$ sorption capacity of the soil is not exceeded (Benbi and Gilkes, 1987). These initial reaction products can be fairly soluble, and with time they transform into more stable $\mathrm{P}$ forms (Lindsay, 1979). In acidic soils, thermodynamics predicts that the fate of $\mathrm{P}$ fertilizers would be the formation of $\mathrm{Al}$ and $\mathrm{Fe}$ phosphates; variscite, strengite, and vivianite are the secondary $\mathrm{P}$ solids that precipitate out, depending on soil conditions such as redox and $\mathrm{Al}$ and Fe solubility (Lindsay 1979). Study of six excessively fertilized soils suggested the presence of amorphous analog of variscite in acidic soils (Pierzynski et al., 1990). At higher $\mathrm{pH}$, the initial $\mathrm{P}$ reaction products formed are usually the soluble $\mathrm{Ca}-\mathrm{P}$ forms (such as brushite, monetite, and dicalcium phosphate), and with time they transform into more stable calcium solid P species (analogs of apatite) (Lindsay, 1979).

In many soil systems, a high proportion of applied $\mathrm{P}$ is rapidly converted to insoluble phosphates that plants have virtually no ability to access. Adoption of various tillage systems might affect the fate and availability of P in soils. Reduced-tillage crop production is gaining more attention from farmers in many regions of the United States and on farms worldwide (Hobbs et al., 2008). Despite various advantages of reduced-tillage systems, granular P applications have been found to lead to an accumulation of available $P$ on the surface $(0-5 \mathrm{~cm})$ soil layer and a depletion of available P deeper in the profile (Schwab et al., 2006), which could be intensified further due to deposition of crop residues. Phosphorus stratified at the soil surface may support plant root growth under moist conditions at initial stages of plant growth; however, roots explore deep soil layers for nutrients and moisture as surface soil dries in summer, so plants may suffer from low nutrient availability. Bordoli and Mallarino (1998) suggested that deep placement of nutrients (below the first $5-10 \mathrm{~cm}$ of the soil) may be superior to other placements such as broadcast when nutrient stratification and topsoil moisture deficits reduce nutrient uptake from shallow soil layers, but inconsistent results have been obtained from research conducted to study the effects of tillage and deeper placement of $\mathrm{P}$ fertilizers on grain yields of crops grown in Kansas soil with P stratification (Schwab et al., 2006). We hypothesized that in a reduced-tillage system, P placement-broadcast vs. deepbanding - can have significant influence on P fertilizer reaction products. If $\mathrm{P}$ is surface applied (i.e., broadcast), $\mathrm{P}$ diffusion from the granules would be slower. So in P-stratified surface soils, P precipitation reactions may be intensified, quickly transforming fertilizer P into more insoluble forms. These effects could be less significant for deep-placed P fertilizers.

Lombi et al. (2004) suggested that liquid forms of P fertilizers are more isotopically exchangeable in highly calcareous Australian soils than granular P forms, and thus are more available to the crops. Holloway et al. (2001) reported that fluid monoammonium phosphate was four to five times more effective than granular monoammonium phosphate in field trials conducted on the same soil types. McBeath et al. (2005) found that wheat biomass was enhanced by $\mathrm{P}$ application in $86 \%$ of the soils tested. In $62 \%$ of the P-responsive soils, wheat dry matter was significantly greater when liquid P fertilizers (phosphoric acid and ammonium polyphosphate) were used compared with the granular form (triple superphosphate), and they related this result to calcium carbonate content of the soils. The superior performance of liquid $\mathrm{P}$ was attributed to the greater outward diffusion of liquid $\mathrm{P}$ from the point of placement compared with granular $\mathrm{P}$, thus reducing the chances of creating microenvironment soil solutions supersaturated with various solid Ca-P species (Lombi et al., 2004; Hettiarachchi et al., 2006; Lombi et al., 2006). We hypothesized that this enhanced or greater $\mathrm{P}$ diffusion would be beneficial for reduced-tillage systems, and that surface or deep-banded liquid P fertilizers may be a suitable alternative for reduced-tillage systems.

Many extractants have been employed for the assessment of available P in soils. Out of those methods, Brayl (Bray and Kurtz, 1945), Mehlich (Mehlich, 1984), and the Olsen procedures (Watanabe and Olsen, 1965) are the commonly used techniques for the determination of available $\mathrm{P}$ (also known as soil test $\mathrm{P}$ ) in soil. These conventional methods for determination of available $P$ in soils generally use a wide range of chemical reactants and may fail to extract plant-available P if they are used in soil types for which they are not appropriate (Sharpley, 1991). Procedures developed to overcome the limitations of chemical extractants include anion resin exchange membrane (Saggar et al., 1990), the iron-sink method (Menon et al., 1990; Sharpley et al., 1994) and isotopic dilution techniques (Salcedo et al., 1991). Unlike conventional soil test $\mathrm{P}$ methods, resin exchange membrane does not use chemical extractant and extracts $\mathrm{P}$ from soils at 
its inherent $\mathrm{pH}$. Anion exchange resin membrane or iron-sink methods function similarly to plant-root surface by adsorbing available or labile P from the soil labile P pool. Resin-based P extraction has been found to be a better predictor of soil-available P (Sharpley, 1991; Sims et al., 2000; Mallarino and Atia, 2005), but its adoption as a routine soil testing method remains limited.

Synchrotron-based X-ray absorption near edge structure (XANES) spectroscopy has emerged as an advanced technique for identification of solid and adsorbed forms of $\mathrm{P}$ in soils (Hesterberg et al., 1999). Samples can be analyzed in the presence of water, making P K-edge XANES a direct in situ method for understanding $\mathrm{P}$ speciation without pretreatment or extraction from soils (Toor et al., 2006). XANES “fingerprinting” methods such as linear combination fitting in conjunction with principal component analysis (PCA) have been used to recreate or match the sample (unknown) spectrum using a known set of standard spectra. Sato et al. (2005) reported P associations with Fe minerals in an acidic forest soil using linear combination fitting of P K-edge XANES spectra. Beauchemin et al. (2003) combined linear combination fitting of $\mathrm{P}$ K-edge XANES with PCA on P-enriched agricultural soils to show that $\mathrm{P}$ was bound in adsorbed forms with $\mathrm{Fe}$ - and Al-oxide minerals, with a higher proportion of adsorbed $\mathrm{P}$ identified in more acidic soils. They also reported $\mathrm{Ca}-\mathrm{P}$ mineral forms in all of the soil samples whose $\mathrm{pH}$ values ranged from 5.5 to 7.6 .

Information on both resin-extractable $\mathrm{P}$ and dominant $\mathrm{P}$ species formed in reduced-tillage soil systems after different $\mathrm{P}$ treatments and placement methods would help us explore whether certain P fertilizers and placement methods result in superior (i.e., maintaining high $\mathrm{P}$ availability) short- and longterm performance in soil and understand reasons or possible mechanisms that explain their superior performance. The objectives of this study were to: (i) study the effects of fertilizer placement (broadcast vs. deep-placed/banded) and source (granular vs. liquid) on reaction products of $\mathrm{P}$ and availability of $\mathrm{P}$ at two different time periods ( $5 \mathrm{wk}$ and $6 \mathrm{mo}$ ), (ii) study the availability of $\mathrm{P}$ at different distances from the point of fertilizer application, and (iii) develop the relationship between $\mathrm{P}$ chemistry and $\mathrm{P}$ availability. We used XANES to determine $\mathrm{P}$ reaction products in soils and a resin membrane technique for determining potential plant-available $\mathrm{P}$.

\section{MATERIALS AND METHODS Site Description, Soil, and Fertilizers}

A field-based study was conducted at the Department of Agronomy North Farm site in Manhattan, KS. This site has a history of more than $10 \mathrm{yr}$ of reduced tillage. The soil at this site is classified as a Smolan silt loam (fine, smectitic, mesic Pachic Argiustolls). Granular monoammonium phosphate (MAP) and technical grade monoammonium phosphate (TGMAP) in liquid form were used as $\mathrm{P}$ fertilizer sources. Nitrogen was applied at a rate of $200 \mathrm{~kg} \mathrm{ha}^{-1}$, and $\mathrm{P}$ was applied at a rate of $75 \mathrm{~kg} \mathrm{ha}^{-1}$. These application rates are based on the total nutrient content of the fertilizers. Phosphorus is often applied with $\mathrm{N}$ to supply plant nutritional requirements. Nitrogen fertilizers that are applied along with $\mathrm{P}$ fertilizers may have the potential to influence $\mathrm{P}$ chemistry in the soil; thus, urea was applied to all the treatments to supply $\mathrm{N}$ by balancing $\mathrm{N}$ from MAP for granular and liquid MAP fertilizer treatments. Before initiating the study, soil samples were extracted to study the general properties of the soil (Table 1). Soil pH was measured in 1:5 soil/water extract (Wateson and Brown, 1998), and cation exchange capacity was determined using the summation method described by Chapman (1965). Mehlich-3 P was determined following the procedures described by Frank et al. (1998). Ammonium acetate-extractable Ca was determined using the procedures described by Warncke and Brown (1998). Extractable Fe and Mn were determined using the DTPA extraction technique described by Whitney (1998), and potassium chloride-extractable Al was determined following the procedures described by McLean (1965). Total $\mathrm{P}$ and $\mathrm{N}$ were determined following the method suggested by Bremner and Mulvaney (1982). Organic matter content was determined following modified Walkley-Black method as described by Combs and Nathan (1998) with a "heat of dilution" modification. Particle size distribution was determined using a modification of the pipette method of Kilmer and Alexander (1949) and method 3A1 form the Soil Survey Laboratory Methods Manual (Soil Survey Laboratory Staff, 2004).

\section{Experimental Approach}

The treatment structure included: (i) urea broadcast $(+\mathrm{N}$ control), (ii) urea deep-band (+N control), (iii) MAP broadcast, (iv) MAP deep-band, (v) TGMAP broadcast, and (vi) TGMAP deep-band. In addition, control broadcast and control deepband samples representing the soil's background P levels were obtained before P treatment application. Experimental design was a randomized complete block with five replications. The plot size was 1.52 by $2.44 \mathrm{~m}$ with a $0.91-\mathrm{m}$ alley between the plots. Broadcast treatments were applied on the surface and gently mixed by hand with the surface $1 \mathrm{~cm}$ of soil, and deepband treatments were applied approximately at a 10-cm depth in two rows per plot using a tractor-driven disc coulter with an

Table 1. Basic properties of North Farm soil.

\begin{tabular}{|c|c|c|c|c|c|c|c|c|c|c|}
\hline \multirow{2}{*}{ Sample depth } & \multirow{2}{*}{$\mathrm{pH}$} & \multirow{2}{*}{ CEC +} & \multicolumn{5}{|c|}{ Extractable } & \multirow{2}{*}{ - Total N Total P } & \multirow{2}{*}{ P OM } & \multirow{2}{*}{$\begin{array}{c}\text { Textura } \\
\text { class }\end{array}$} \\
\hline & & & M3P & $\mathrm{Ca}_{\mathrm{ac}}$ & $\mathrm{Fe}_{\mathrm{dtpa}}$ & $M n_{d t p a}$ & $\overline{\mathrm{Al}^{3+}{ }_{\mathrm{KC}}}$ & & & \\
\hline $\mathrm{cm}$ & & $\mathrm{nol}_{\mathrm{C}} \mathrm{kg}^{-1}$ & 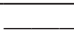 & 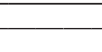 & 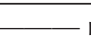 & $\mathrm{mg} \mathrm{kg}^{-1}$ & & & $\%$ & \\
\hline $0-7$ & 5.9 & 16.1 & 45.4 & 2426.0 & 7.9 & 58.3 & 0.0 & 1598.0423 .0 & 3.2 & SiL \\
\hline $7-15$ & 5.7 & 20.3 & 19.6 & 2540.0 & 8.2 & 57.8 & 0.4 & 1114.0329 .0 & 2.3 & $\mathrm{SiCL}$ \\
\hline $15-30$ & 6.1 & 18.8 & 5.9 & 3174.0 & 27.8 & 25.0 & 0.1 & 1119.0278 .0 & 2.2 & $\mathrm{SiCL}$ \\
\hline
\end{tabular}

+ CEC, cation exchange capacity; M3P, Mehlich III-extractable phosphorus; $\mathrm{Ca}_{\mathrm{ac}}$ ammonium acetateextractable calcium; $\mathrm{Fe}_{\mathrm{dtpa}}$ and $\mathrm{Mn}_{\mathrm{dtpa}^{\prime}}$ diethylene triamine pentaaceticacid-extractable iron and manganese; $\mathrm{Al}_{\mathrm{KCl}}$, potassium chloride extractable aluminum; $\mathrm{OM}$, organic matter content; SiL, silty loam; $\mathrm{SiCL}$, silty clay loam. 
arrangement for running a twine on the deep-banded zone for relocating the exact position for sampling. The distance between the rows for each deep-band treatment was maintained at $76.2 \mathrm{~cm}$ (i.e., two rows $76.2 \mathrm{~cm}$ apart per treatment). The total amount of fertilizer for each deep-band treatment was divided equally between these two rows and applied uniformly along the bands/rows. The study was conducted without plants, and weeds were controlled with periodic hand-weeding. Soil samples were collected at $5 \mathrm{wk}$ and 6 mo from treatment application time. Sampling was done by extracting $30-\mathrm{cm}$ soil cores using a probe and separating 2.5-cm-long soil sections for separate analysis. For broadcast treatments, six representative soil cores from each plot were taken, separated into 2.5 -cm-long soil sections, and mixed depth-wise. For deep-band treatments, three $30-\mathrm{cm}$ soil cores from each row were extracted, separated into 2.5-cm-long sections, and mixed depth-wise. Soil samples were then air-dried and sieved with a $2-\mathrm{mm}$ sieve before analysis. For broadcast treatments, soil samples from the top three layers (i.e., 0-2.5, 2.5-5, and 5-7.5 cm) were analyzed, and for deepband treatments soil samples from 5-7.5, 7.5-10, 10-12.5, and $12.5-15 \mathrm{~cm}$ were analyzed. Statistical analysis of all data was performed using the PROC MIXED procedure in SAS (SAS 9.1, SAS Institute, 2007). The pairwise Bonferroni method was used for pairwise comparisons between treatments at $\alpha=0.05$ level of significance.

\section{Wet Chemical Analysis}

The wet chemical-based analysis included measurement of $\mathrm{pH}$, total $\mathrm{P}$, and resin-extractable $\mathrm{P}$ (using anion exchange resin membrane) at different distances from the point of fertilizer application. Soil $\mathrm{pH}$ was determined using a 1:5 soil/ water ratio (Thomas, 1996). Total $\mathrm{P}$ was determined using the modified salicylic sulfuric acid digestion method using inductively coupled plasma optical emission spectroscopy (ICP-OES) as described by Bremner and Mulvaney (1982). Resin-extractable $\mathrm{P}$ was determined following the procedure of Myers et al. (2005). Resin membrane BDH product no. $55164 \mathrm{~S}$ was used for the resin P extraction procedure (U.S. distributor: CTL Scientific Supply Corp., Deer Park, NY). The resin membrane comes in a pack of six $12.5-$ by $12.5-\mathrm{cm}$ sheets. The resin membrane was cut into $5-$ by $2.5-\mathrm{cm}$ pieces, saturated with $0.5 \mathrm{M} \mathrm{NaHCO}_{3}$, and two strips were used for $1.0 \mathrm{~g}$ of soil used for extraction. Phosphorus was extracted as described by Myers et al. (2005). Basically, $1.0 \mathrm{~g}$ of soil was placed in a polyethylene container containing $80 \mathrm{~mL}$ of water. Two resin strips were added to the container and shaken in an orbital shaker for $24 \mathrm{~h}$. After shaking, the resin strips were removed from the container, washed with deionized water to remove any adhering soil particles, and transferred to another polyethylene container with $50 \mathrm{~mL}$ of $0.5 \mathrm{M}$ hydrochloric acid $(\mathrm{HCl})$. The resin strips in $0.5 \mathrm{M} \mathrm{HCl}$ solution were shaken for an additional $1.5 \mathrm{~h}$, filtered using Whatman filter paper no. 2 , and analyzed colorimetrically using method of Murphy and Riley (1962).

\section{Speciation of Phosphorus}

\section{X-ray Absorption Near Edge Structure Spectroscopy Data Collection}

Phosphorus K-edge XANES data were collected at Sector 9-BM-B, Advanced Photon Source (APS), Argonne National Laboratory, Argonne, IL. The electron storage ring at the APS is operated at $7 \mathrm{GeV}$ with a maximum current of $100 \mathrm{~mA}$. This beamline has an energy range of 2.1 to $23 \mathrm{keV}$ and is equipped with a $\mathrm{Si}$ (III) monochromator with a focused beam size of 500 by $500 \mu \mathrm{m}$. The sample compartment was He-purged, and data were collected in fluorescence mode using a four element Vortex Si-Drift detector (SII Nano Technology USA Inc., Northridge, $\mathrm{CA})$. The phosphorus pentoxide $\left(\mathrm{P}_{2} \mathrm{O}_{5}\right)$ standard was used for monochromator calibration. Correction in any energy drifts caused by monochromator drifts were done by collecting spectra of $\mathrm{P}_{2} \mathrm{O}_{5}$ daily during runtime. All samples and standards were calibrated using a common energy scale by setting the first derivative spectrum of apatite to $2149.25 \mathrm{eV}$ for analysis.

Pre-application samples were extracted from the field before application of the fertilizer treatments. The top 0 to $7 \mathrm{~cm}$ of soil for broadcast and the 7 - to 15 -cm depth for deep-band treatments were used as two additional controls (zero $\mathrm{N}$ and $\mathrm{P}$ ) for the XANES study. A single replication of soil samples from the top 0 to $2.5 \mathrm{~cm}$ for broadcast treatments and 7.5- to 10-cm depth for deep-banded treatments was used for the speciation study. The soil samples were air-dried and ground to pass through a $<150-\mu \mathrm{m}$ sieve. The samples were ground further with an agate mortar and pestle, and soil pellets $4 \mathrm{~mm}$ in diameter were prepared using a $\mathrm{KBr}$ quick press kit with a 4-mm die set (International Crystal Laboratories, Garfield, NJ) to compact samples for a better signal. The quality of P-XANES collected improved with a decrease in particle size (data not shown). Grinding of samples below $150 \mathrm{~mm}$ enhanced the quality of P-XANES data compared with samples that passed only the 150-mm sieve. The samples were then mounted on Teflon tape and fixed on $\mathrm{Al}$ sample holders ready for analysis. Four to six scans of samples were taken with a scan range from 2110 to $2400 \mathrm{eV}$. The step size was $2.0 \mathrm{eV}$ on the pre-edge region (2110$2140 \mathrm{eV}), 0.125 \mathrm{eV}$ in the near-edge region (2140-2165 eV), and 0.5 in the post-edge region $(2165-2400 \mathrm{eV})$ with a reading time of 3 to 6 s per point. Four to six scans of collected spectra for particular samples were averaged, the edge energy was calibrated, the pre-edge was subtracted (by a linear function), and the spectrum was normalized to the second-order polynomial to be equal to 1 . Normalization was done using Athena software version 0.8.056 (Ravel and Newville, 2005).

The $\mathrm{P}$ standards used in this study were purchased or synthesized. Berlinite $\left(\mathrm{AlPO}_{4}\right)$, brushite $\left(\mathrm{CaHPO}_{4} \cdot 2 \mathrm{H}_{2} \mathrm{O}\right)$, hydroxyapatite $\left[\left(\mathrm{Ca}_{5}\left(\mathrm{PO}_{4}\right)_{3}(\mathrm{OH})\right]\right.$, monetite $\left(\mathrm{CaHPO}_{4}\right)$, and rock phosphate were purchased from Sigma Aldrich (St. Louis, $\mathrm{MO})$. Strengite $\left(\mathrm{FePO}_{4} \cdot 2 \mathrm{H}_{2} \mathrm{O}\right)$ was synthesized following the procedure of Dalas (1991). Strengite with different crystallinities was synthesized. Variscite $\left(\mathrm{AlPO}_{4} \cdot 2 \mathrm{H}_{2} \mathrm{O}\right)$ was synthesized following the procedure of Hsu and Sikora (1993). Vivianite and apatite standards were obtained from the University of Adelaide, 
Australia. Phosphorus pentoxide $\left(\mathrm{P}_{2} \mathrm{O}_{5}\right)$ was purchased from Alfa Aesar (Ward Hill, MA). Adsorbed phosphate on goethite and alumina were prepared following the procedure of $\mathrm{Oh}$ et al. (1999). Ferrihydrite and gibbsite adsorbed P were prepared following the procedure of Schwertmann and Cornell (1991). The purity of synthesized $\mathrm{P}$ standards was verified using X-ray diffraction. The powdered phosphate standards were spread as a thin layer over double-sided $\mathrm{C}$ tape and mounted on $\mathrm{Al}$ samples holders for XANES data collection. Two scans per each standard in fluorescence mode were collected as previously described.

\section{Data Analysis \\ Principal Component Analysis}

The normalized XANES spectra were analyzed using PCA. Principal component analysis was conducted with the LabView software package available from Beamline 10.3.2 of Advanced Light Source (Marcus et al., 2004) to see how many spectra were linearly independent in samples and how many principal components (PC) were needed to reproduce the spectrum. Principal component analysis first considers the statistical variance within an experimental dataset composed of a group of unknown samples. The dataset is then redefined into a reduced number of independent sources of variability. A subsequent analysis, the target transformation, offers the possibility of testing which standard species are most likely to contribute to the PC.

A mechanical mixture of chemical species obviously results in a linear combination of the corresponding spectra; however, if different species have similar XANES spectra, the spectra may be linearly dependent even for a set of pure chemical species. The spectra subjected to PCA or target transformation are defined on the same energy grid. By loading sample spectra into PCA software, we obtained eigenvalues, indicator (IND) values, and signal and reconstructed curves. The eigenvalues measure the amplitude of the abstract spectra of the factors. Factors with large eigenvalues influence the data more than factors with small eigenvalues. The eigenvalue rule is one way to determine the number of significant principal components. If the eigenvalues are very small or do not change significantly, we could consider the eigenvalues insignificant. The criterion described by Beauchemin et al. (2003) and Nachtegaal et al. (2005) was used to define the number of significant components. The IND function is an empirical method that relies on the secondary eigenvalues; it should reach a minimum value when the correct number of significant components is reached. The standards were selected based on the SPOIL value. The SPOIL function indicates whether the vector of the soil standard tested fits well or increases the error in the matrix reproduced in the target transformation. A target is considered acceptable if its SPOIL value is $<3$, moderately acceptable if the value is 3 to 6 , and unacceptable if the value is $>6$ (Malinowski, 1991). The SPOIL values for standards are listed in Table 2.
Table 2. SPOILt factors for the reference spectra constructed from principal components.

\begin{tabular}{|c|c|c|}
\hline Reference & 5-wk samples & 6-mo samples \\
\hline Al. phosphate & 1.43 & 1.47 \\
\hline Apatite & 1.85 & 1.85 \\
\hline Brushite & 1.66 & 1.73 \\
\hline Hydroxyapatite & 1.83 & 1.88 \\
\hline Pot. Dihydrogen phosphate & 1.79 & 1.90 \\
\hline Monetite & 1.82 & 1.93 \\
\hline Monoammonium phosphate & 1.80 & 1.92 \\
\hline Alumina adsorbed $\mathrm{P}$ & 2.27 & 2.77 \\
\hline Ferrihydrite adsorbed $\mathrm{P}$ & 2.26 & 2.58 \\
\hline Gibbsite adsorbed P & 1.90 & 1.95 \\
\hline Goethite adsorbed P & 1.98 & 2.03 \\
\hline Rock phosphate & 1.96 & 2.02 \\
\hline Poorly crystalline Strengite & 1.97 & 2.07 \\
\hline Strengite & 1.80 & 1.90 \\
\hline Variscite & 1.95 & 1.95 \\
\hline Vivianite & 2.07 & 2.16 \\
\hline
\end{tabular}

\section{Linear Combination Fitting}

The XANES data were analyzed with Athena software. Speciation was done using linear combination fitting (LCF). The linear combination XANES fitting procedure reconstructs the sample (or experimental) spectra using all combinations of the standard spectra. The weighting factors were forced to sum to 1 , and no energy shifts were permitted in LCF fitting. Out of all possible combinations, the combination with the lowest reduced $\chi^{2}$ value was chosen as the most likely set of components or the best fit. The fitting was done in the normalized space using quaternary combinations of all standards with the fitting range from 2144 to $2179 \mathrm{eV}$ because the PCA indicated that four principal components were needed to reproduce the soil P-XANES spectra.

\section{RESULTS AND DISCUSSION Wet Chemical Analysis}

Figure 1 for the response variables shows a statistical comparison of various treatments at the point of fertilizer application; that is, at $0-$ to $2.5-\mathrm{cm}$ depth for the broadcast treatment with 7.5- to 10-cm depth for deep-banded. The initial soil $\mathrm{pH}$ values for the top 0 - to $7-\mathrm{cm}$ and 7 - to $15-\mathrm{cm}$ soil depths were 5.9 and 5.7, respectively (Table 1). Addition of fertilizers showed a decrease in soil $\mathrm{pH}$ at 5 wk; however, $\mathrm{pH}$ moved toward initial soil pH at 6 mo for most of the treatments. Mixed results (lower, higher, or no significant difference) were observed for soil $\mathrm{pH}$ when comparing $\mathrm{pH}$ changes among the ureaadded plots and the plots with both urea and MAP (as granular or liquid) added (Fig. 1). Many researchers have reported acidification effects of MAP on soil pH (Hanson and Westfall, 1985; Moody et al., 1995), but hydrolysis of urea consumes 2 moles of protons for each mole of urea hydrolyzed, thereby resulting in an increase in $\mathrm{pH}$. Therefore, a combination of these 
(A)

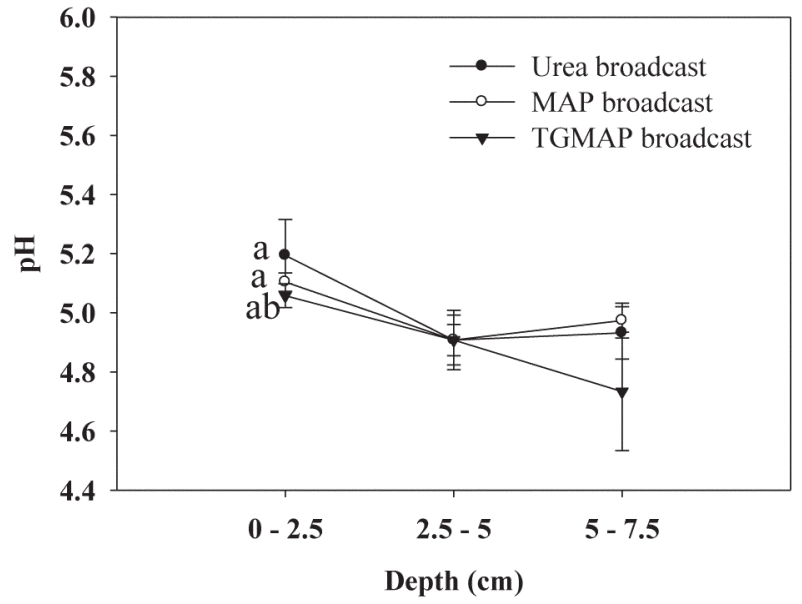

(C)

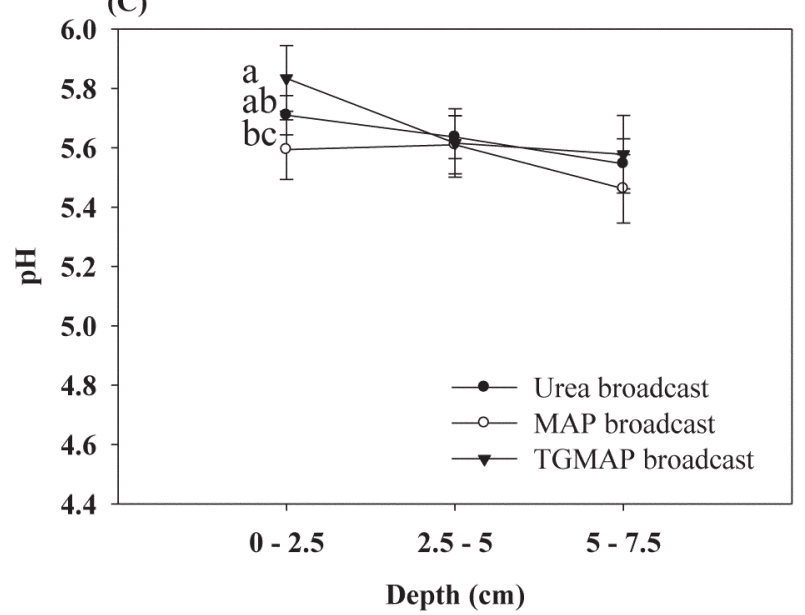

(B)

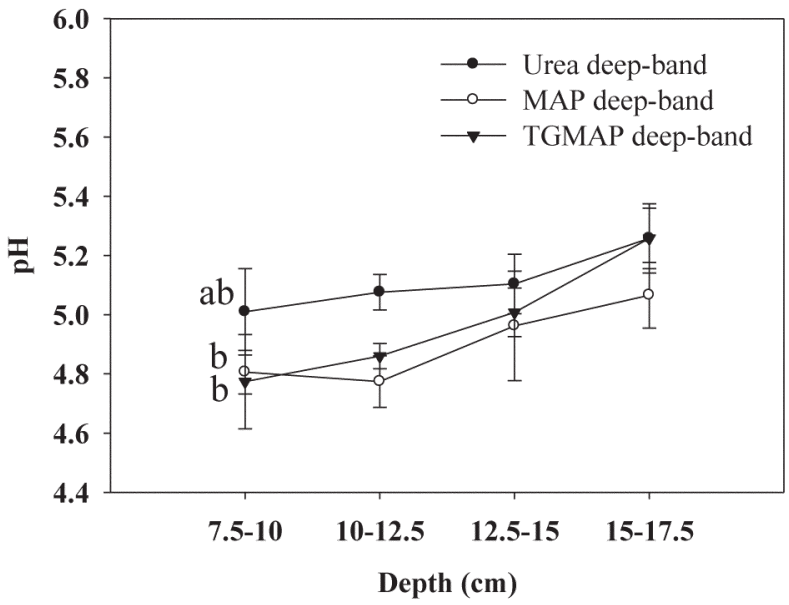

(D)

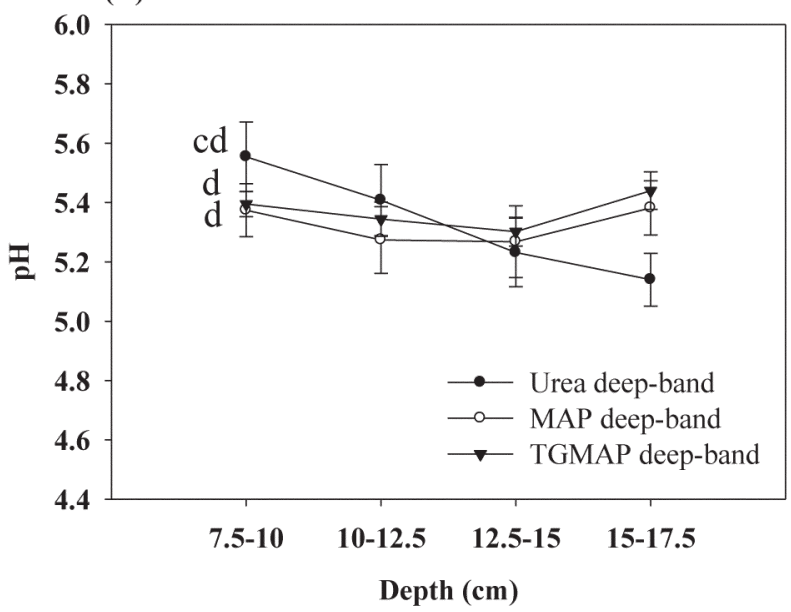

Fig. 1. pH at different distances from the point of fertilizer application over time: (A) 5 wk broadcast, (B) 5 wk deep-band, (C) 6 mo broadcast, and (D) 6 mo deep-band. Granular monoammonium phosphate (MAP) = MAP; liquid MAP = technical grade monoammonium phosphate (TGMAP).

reactions (nitrification of $\mathrm{NH}_{4}{ }^{+}$and hydrolysis of urea) could in turn result in mixed effects on overall soil $\mathrm{pH}$. At $5 \mathrm{wk}$, soil $\mathrm{pH}$ in both urea and MAP (as granular or liquid) added with broadcast and deep-banded treatments were significantly lower (0.6-1 units) than the original soil $\mathrm{pH}$ (5.9), whereas the soil $\mathrm{pH}$ of broadcast $P$ treatments at 6 mo was found restored to initial soil $\mathrm{pH}$ (Fig. 1). At $6 \mathrm{mo}$, the soil $\mathrm{pH}$ for the deep-banded treatments was lower (0.2-0.6 units) than the soil $\mathrm{pH}$ at $5 \mathrm{wk}$ from the same plots (i.e., that received same soil treatment). This result is most likely due to neutralization of treatment effects on soil $\mathrm{pH}$ with time and in-field seasonal variation of soil $\mathrm{pH}$.

As expected, we found no difference in total P (Fig. 2) for granular MAP and liquid MAP treatments, and we observed no differences with respect to time. The broadcast urea had slightly higher total P content (average of $488.1 \mathrm{mg} \mathrm{kg}^{-1}$ ) compared with the deep-banded urea treatment (average of $350.3 \mathrm{mg} \mathrm{kg}^{-1}$ ), which might be due to the P stratification in the reduced-tillage system.

We used an anion exchange membrane technique (resinextractable P) to estimate potential available P in soils (Fig. 3). The $\mathrm{P}$ supplying power of soils assessed by the anionic exchange membrane technique has been shown to correlate satisfactorily with $\mathrm{P}$ uptake and $\mathrm{P}$ concentration in the biomass; therefore, resin-extractable $\mathrm{P}$ can be considered a reliable index of available $P$ in soils (Myers et al., 2005). At 5 wk, deep-banded liquid MAP had the highest resin-extractable $P$ compared with other treatments, and the trend continued even after 6 mo, when resinextractable P remained significantly higher (Fig. 3). We also examined resin-extractable $\mathrm{P}$ as a percentage of total $\mathrm{P}$ because it allowed evaluating resin-extractable $P$ independent of the total $\mathrm{P}$ concentrations in soils. At $5 \mathrm{wk}$ for broadcast and deep-band urea plots, the percentages of resin-extractable P concentrations were 3.4 and 9.2, respectively (Fig. 4). For broadcast treatments at $5 \mathrm{wk}$, there was no significant difference in percentage resinextractable P. For the deep-band treatments at $5 \mathrm{wk}$, liquid MAP deep-band had a significantly higher percentage of resin-extractable $\mathrm{P}$ followed by MAP deep-band. Additionally, percentage resin-extractable $\mathrm{P}$ at $5 \mathrm{wk}$ for liquid MAP deepband was significantly higher than all the other treatments. At 6 mo, we found no significant difference in percentage resinextractable P for all broadcast treatments (Fig. 4). In the deepband P plots, both the granular and liquid treatments had a significantly higher percentage of resin-extractable $\mathrm{P}$ than urea and MAP broadcast. For the deep-band treatments at 6 mo, liquid MAP deep-band had a significantly higher percentage of 
(A)

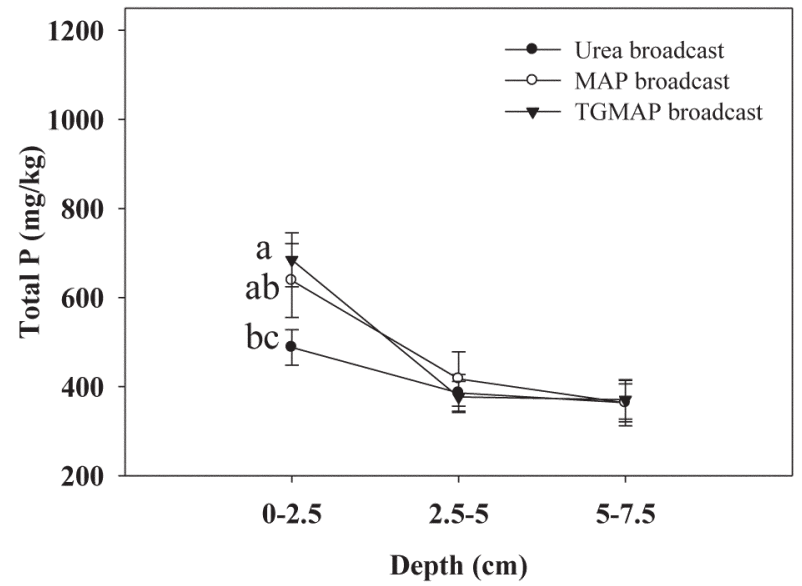

(C)

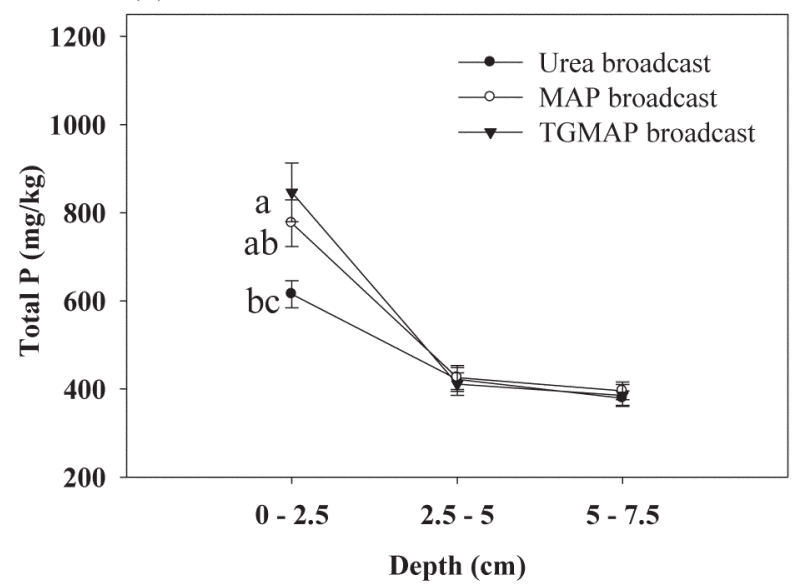

(B)

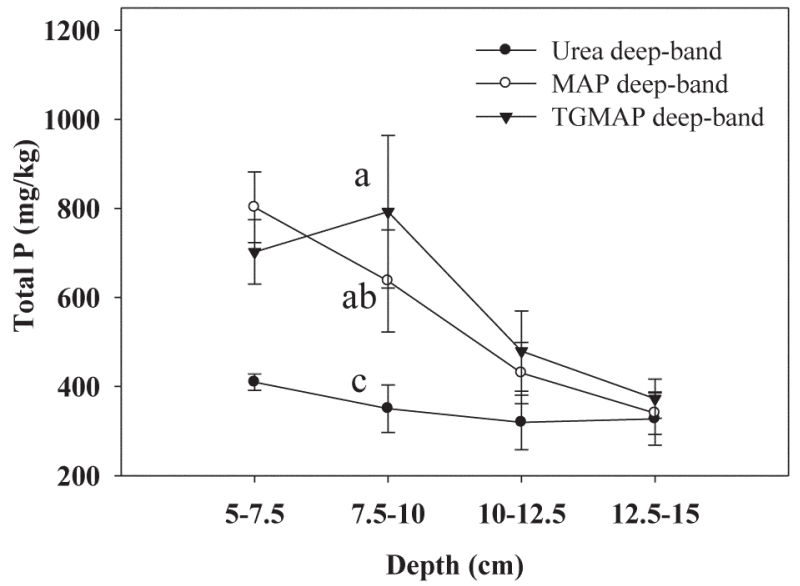

(D)

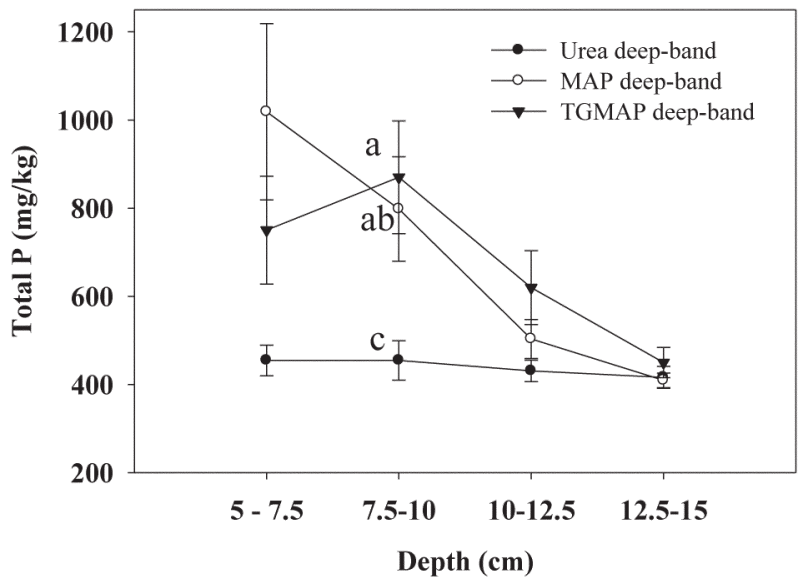

Fig. 2. Total $P$ at different distances from the point of fertilizer application over time: (A) 5 wk broadcast, (B) 5 wk deep-band, (C) 6 mo broadcast, and (D) 6 mo deep-band. Granular monoammonium phosphate (MAP) = MAP; liquid MAP = technical grade monoammonium phosphate (TGMAP).

resin-extractable P. Despite liquid MAP deep-band's significantly higher percentage of resin-extractable $\mathrm{P}$ at $6 \mathrm{mo}$, MAP deepband did not differ significantly from urea deep-band. Only the deep-band liquid treatment had a significantly higher percentage of resin-extractable P compared with all other treatments at 6 mo.

\section{X-ray Absorption Near Edge Structure Analysis}

$\mathrm{X}$-ray absorption near edge structure spectra of standards used for the study are shown in Fig. 5. The white line peak was around $2149 \mathrm{eV}$. Spectra for Fe-phosphate standards showed a pre-edge feature between 2144 and $2147 \mathrm{eV}$, which increased with increasing crystallinity. All calcium phosphate minerals have a shoulder on the high-energy side between 2151 and $2155 \mathrm{eV}$. Aluminum phosphate minerals are characterized by weak pre-edge inflection at about $2148 \mathrm{eV}$. These spectral features of phosphate bond with $\mathrm{Ca}, \mathrm{Al}$, and $\mathrm{Fe}$ and have been well documented (Hesterberg et al., 1999; Peak et al., 2002; Beauchemin et al., 2003; Khare et al., 2005; Lombi et al., 2006), which helps us determine the association of phosphate with different elements in soil samples.

The SPOIL values for all the standards used for the study were $<3$, indicating that all standards were suitable for linear combination (LC)-fitting (Table 2). In the whole-spectrum (whole energy range) PCA component plot (Fig. 6), only the score plots for PC1 and PC2 are presented. The PC1 and PC2 explained 69.5 and $20.6 \%$ of the sample spectral variation, respectively. In the PCA component plot, more similar spectra are located closer to each other, so the PCA component plots can be used to identify groupings of samples. For example, the 5-wk samples were found to be closely located or similar to apatite, hydroxyapatite, monetite, brushite, vivianite, etc., whereas the 6-mo samples were closer to variscite, aluminum phosphate, and adsorbed P forms. Moreover, 6-mo samples were very similar to the spectra of the control soils, suggesting that with time, $\mathrm{P}$ reaction products transform into forms similar to the soil's original P forms. Further PCA of the samples within the preedge energy range (2145.5-2148 eV) and the post-edge energy range (2150-2155.5 eV) showed that the PC1 explained at least $91.5 \%$ of spectral variation.

The normalized P K-edge XANES spectra and linear combination fitting results of 5-wk and 6-mo samples are shown in Fig. 7. Phosphorus was present as adsorbed $\mathrm{P}(68 \%)$ and Fe-P mineral forms (32\%) in the control soil at $5 \mathrm{wk}$ based on XANES fitting analyses (Table 3). Addition of urea lowered adsorbed $\mathrm{P}$ and increased $\mathrm{Fe}-\mathrm{P}$ forms. The broadcast placement of MAP in a granular form further increased the proportion of $\mathrm{P}$ associated 

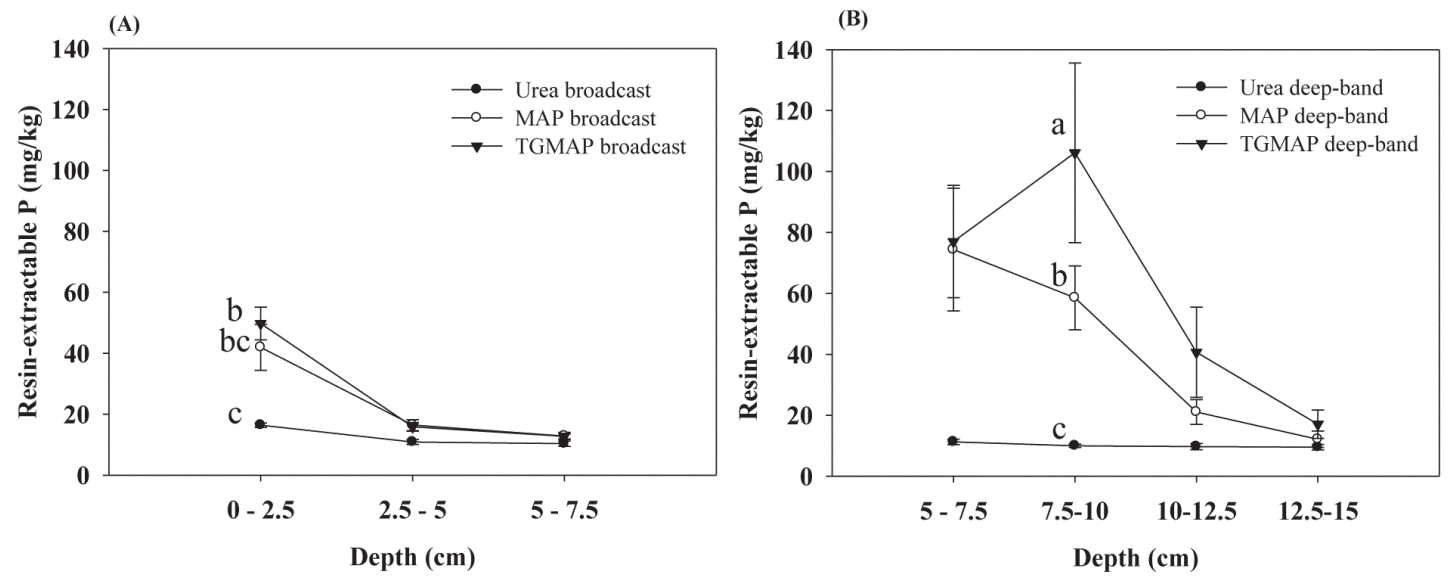

(C)

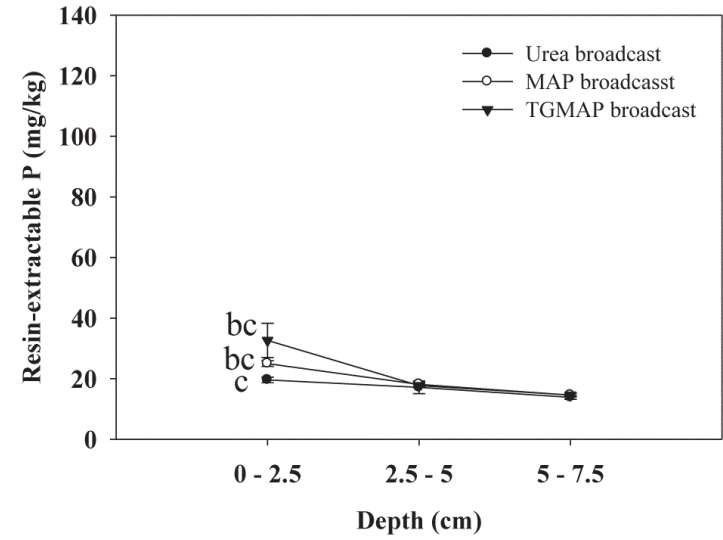

(D)

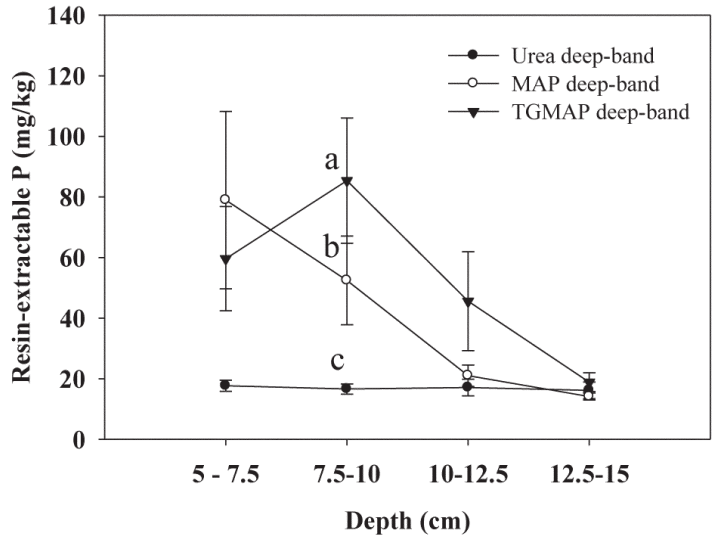

Fig. 3. Resin-extractable P at different distances from the point of fertilizer application over time: (A) 5 wk broadcast, (B) 5 wk deep-band, (C) 6 mo broadcast, and (D) 6 mo deep-band.

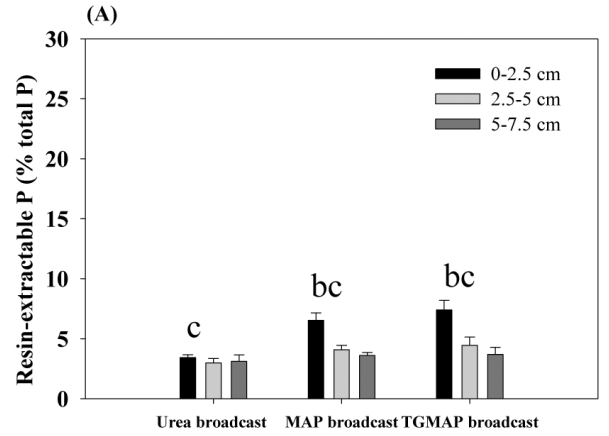

(C)

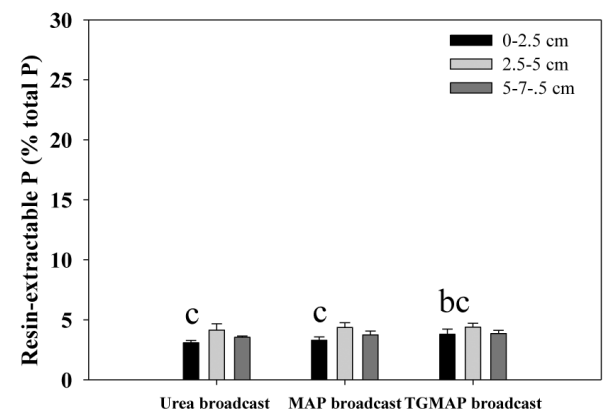

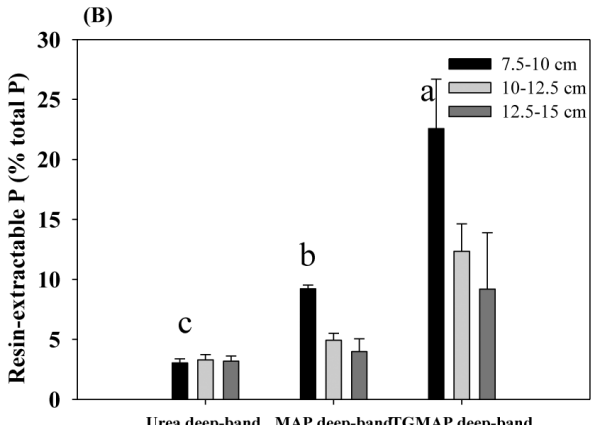

(D)

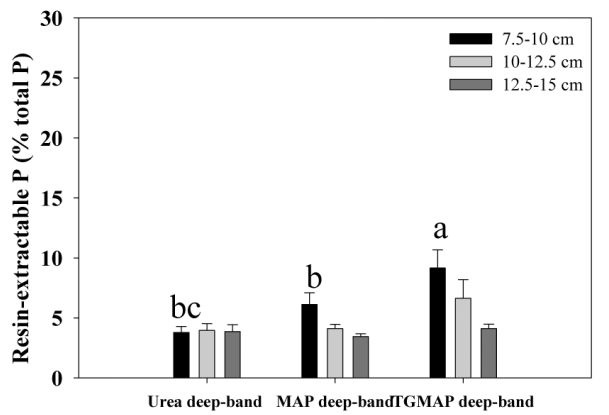

Fig. 4. Resin-extractable $P$ (as percentage of total $P$ ) in soil sections collected at different distances from the point of fertilizer application. The resin-extractable $\mathbf{P}$ (as a percentage of total $P$ ) was calculated by dividing resin-extractable $P$ values for each section by the corresponding total $P$ concentration. Error bars represent standard errors of five field replicates. (A) 5 wk broadcast, (B) 5 wk deep-band, (C) 6 mo broadcast, and (D) 6 mo deep-band treatments. Granular monoammonium phosphate (MAP) = MAP; liquid MAP = technical grade monoammonium phosphate (TGMAP). 

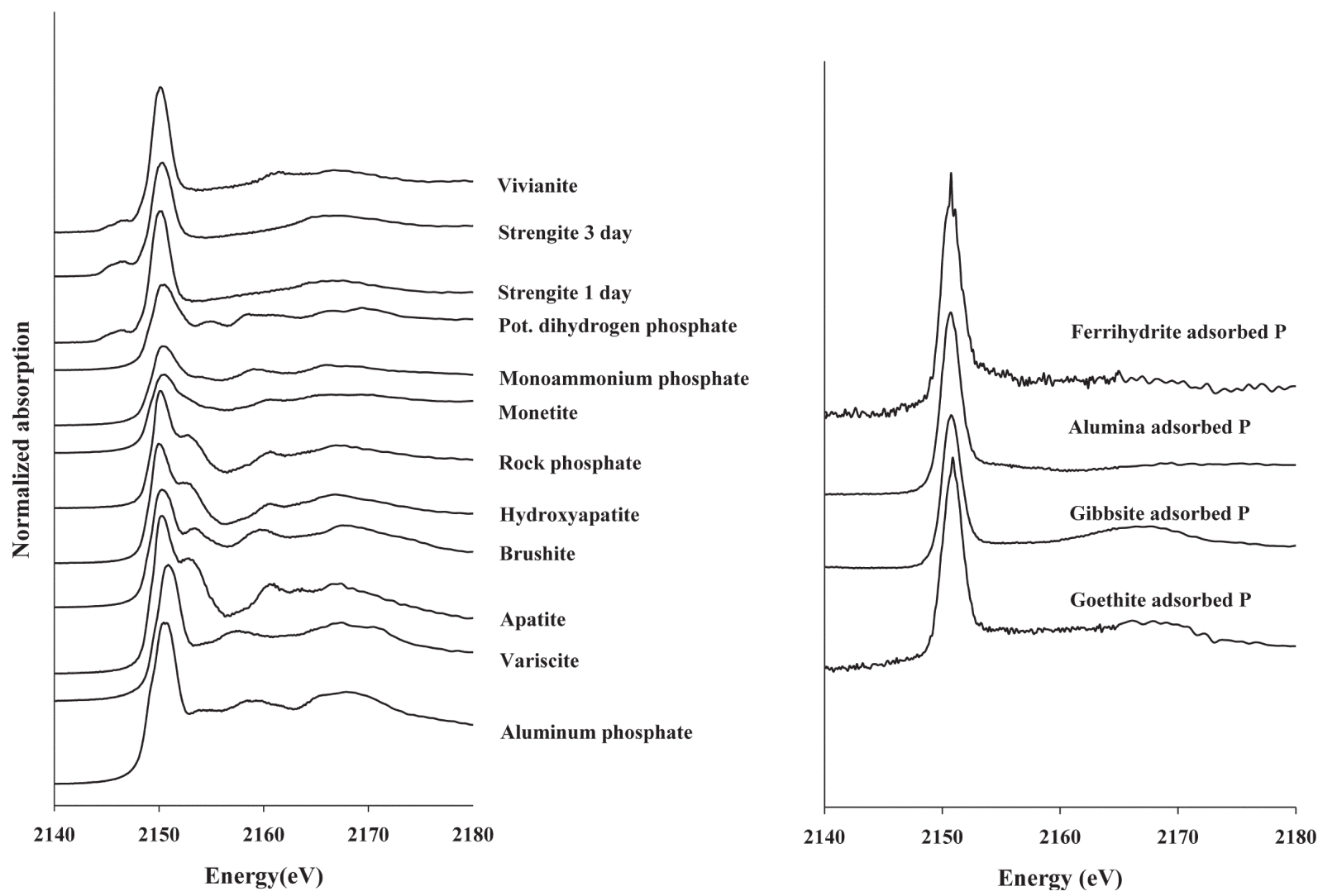

Fig. 5. Normalized P K-X-ray absorption near edge structure (XANES) of standards used for linear combination fitting.

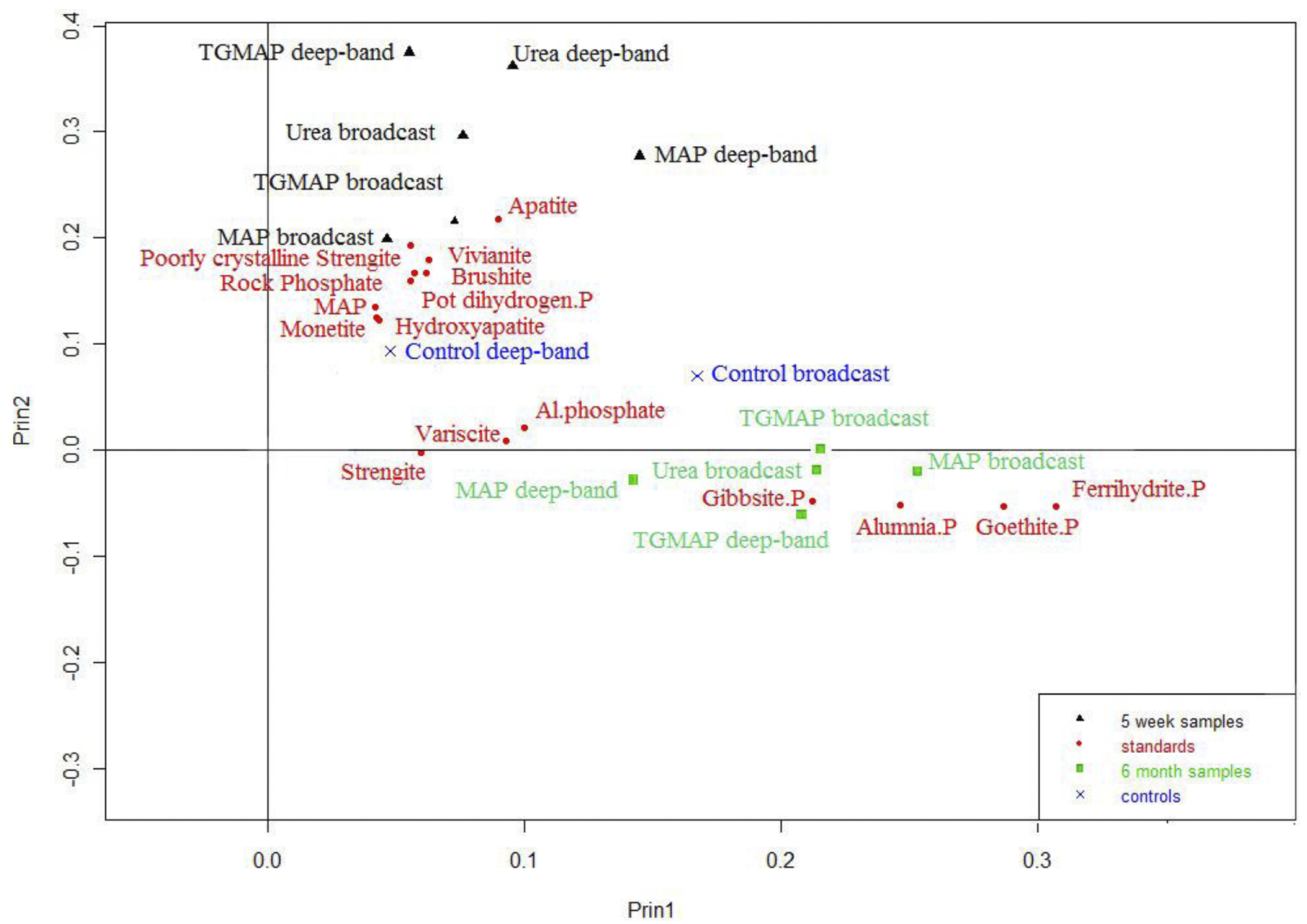

Fig. 6. Principal component (PC) loading plot of standards for 5-wk and 6-mo soil samples. Eigenvectros of all standards and samples across the full spectral range (2144-2179 eV) are presented in the loading plot. 

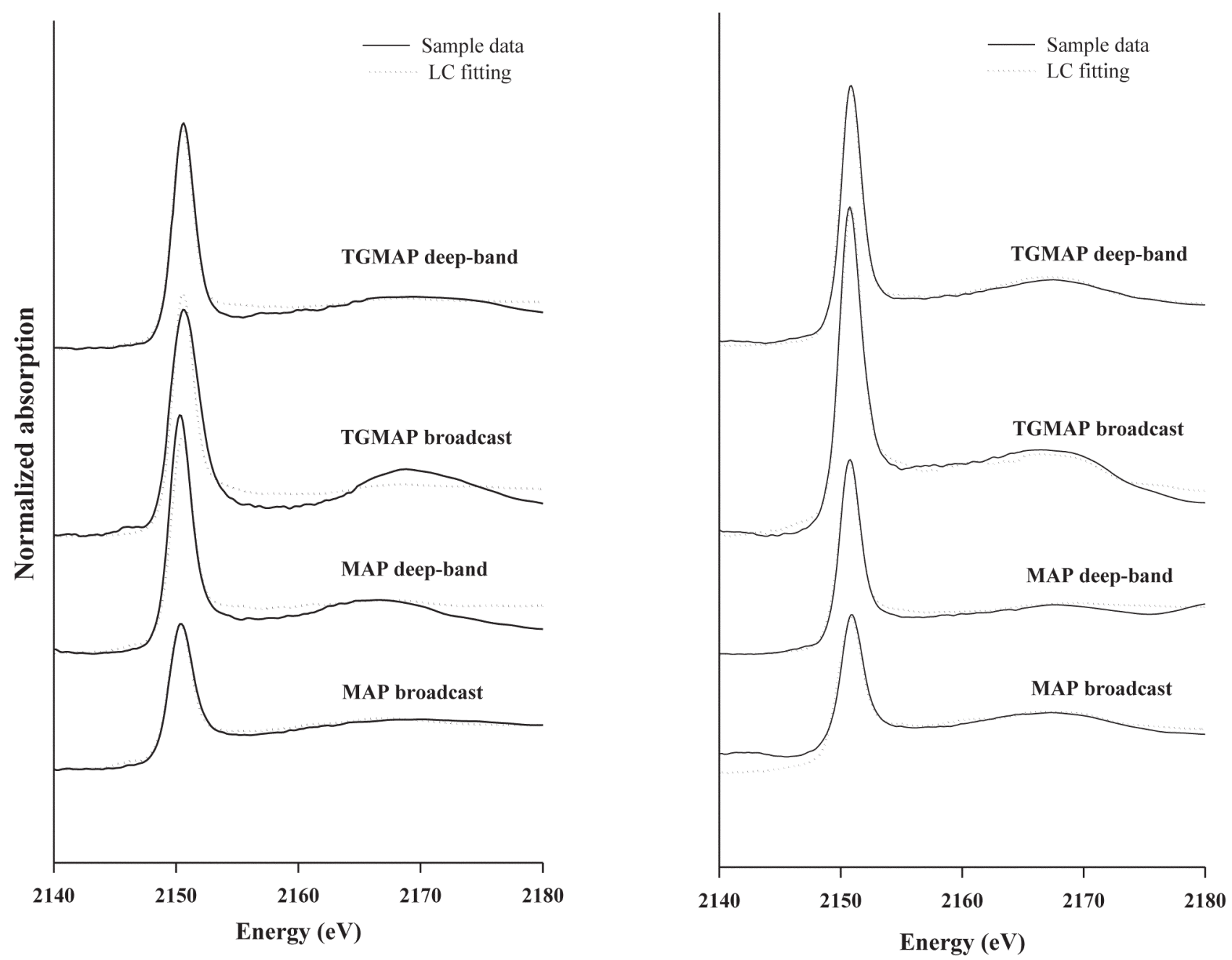

Fig. 7. Normalized P K-X-ray absorption near edge structure (XANES) spectra (solid lines) of soil samples. (A) 5-wk samples, (B) 6-mo samples. Dotted lines indicate the linear combination fits using all the standard compounds.

with $\mathrm{Fe}-\mathrm{P}$ minerals to $72 \%$ and lowered the percentage of adsorbed $\mathrm{P}$ forms to $23 \%$. The remaining $\mathrm{P}$ was present as $\mathrm{Ca}-\mathrm{P}$ minerals $(5 \%)$. The increase in precipitated $\mathrm{Fe}-\mathrm{P}$ forms with

Table 3. Phosphorus K-X-ray absorption near edge structure (XANES) fitting results for 5 -wk samples performed in normalized space with an energy range from 2144 to $2179 \mathrm{eV}$ showing the relative proportion of phosphate minerals showing best fit.

\begin{tabular}{lccccc}
\multicolumn{1}{c}{ Treatment } & Ca-P minerals & Al-P minerals & Fe-P minerals & Adsorbed P & Red. $\mathbf{\chi 2}+$ \\
\hline Control broadcast & - & - & 32.0 & 68.0 & 0.010 \\
Urea broadcast & - & - & 56.8 & 43.2 & 0.053 \\
MAP broadcast & 5.0 & - & 72.5 & 22.5 & 0.004 \\
TGMAP broadcast & 24.0 & - & - & 76.0 & 0.077 \\
Control deep-band & 6.4 & 39.7 & 53.9 & - & 0.098 \\
Urea deep-band & 53.7 & 23.4 & 15.4 & 7.5 & 0.030 \\
MAP deep-band & - & - & 49.0 & 51.0 & 0.098 \\
TGMAP deep-band & - & - & 36.9 & 63.1 & 0.015 \\
\hline
\end{tabular}

$\dagger \chi 2=\Sigma($ fit- data $) / \varepsilon]^{2} /\left(\mathrm{N}_{\text {data }}-\mathrm{N}_{\text {components }}\right)$ is the reduced chi-square statistic. Here, $\varepsilon$ is the estimated uncertainty in the normalized XANES data (taken as 0.01 for all data). The sum is over $\mathrm{N}_{\text {data }}$ points (185 data points between $\mathrm{E}=2144$ and $2179 \mathrm{eV}$ for all data), and $\mathrm{N}_{\text {components }}$ is the number of components in the fit (either 2 or 3 as indicated in the Table). The total percentage was constrained to be $100 \%$ in all fits. Typical uncertainties in the percentages listed for each standard component are $5 \%$.

₹ MAP, monoammonium phosphate; TGMAP, technical grade monoammonium phosphate. broadcast MAP in granular form could be due to the drop in soil $\mathrm{pH}$ from 5.9 in the control to 5.1 after $5 \mathrm{wk}$ as previously mentioned (see Fig. 1). Iron phosphates are known to control solubility of $\mathrm{P}$ under acidic conditions (Lindsay, 1979). In addition, limited diffusion of $\mathrm{P}$ away from MAP granules might have encouraged locally high $\mathrm{P}$ concentrations and subsequent precipitation of $\mathrm{Fe}-\mathrm{P}$ forms (Lombi et al., 2006).

Addition of MAP in a liquid, broadcast form (TGMAP broadcast) resulted in a majority of the $\mathrm{P}$ existing as adsorbed forms (76\%) and the remainder as Ca-P minerals (24\%) after 5 wk (Table 3). No Fe-P minerals were present in the TGMAP broadcast experiments. The lower proportion of precipitated forms of $\mathrm{P}$ in liquid $\mathrm{P}$ treatments when compared with granular $P$ treatments agrees with our initial hypothesis. A plausible explanation 
for the differences between granular and liquid treatments might be greater diffusion of $\mathrm{P}$ in liquid MAP. Lombi et al. (2006) showed that liquid MAP had a greater diffusion rate than granular MAP. We might expect this to result in more diffuse concentrations of $\mathrm{P}$, and conditions might be undersaturated with respect to potentially precipitating $\mathrm{Fe}-\mathrm{P}$ phases.

The second hypothesis was that deep-banding of P would result in lower precipitated forms of $\mathrm{P}$ than for broadcast placement. This was true of granular MAP. Linear combination fitting results showed granular MAP deep-banded into the soil lowered the proportion of precipitated P forms from $77 \%$ with broadcast placement to $49 \%$ in deep placement after $5 \mathrm{wk}$ (Table $3)$. The rest of the $\mathrm{P}$ (51\%) was present in adsorbed forms. Native $\mathrm{P}$ in the control and urea deep-placed treatments was present entirely in precipitated forms ( $>90 \%)$. Notably, these two soils did not receive any $\mathrm{P}$ and therefore had considerably low total $\mathrm{P}$ concentrations that resulted in noisier XANES spectra and weak fits. Addition of deep-placed liquid MAP resulted in a shift from Ca-associated P (with broadcast placement) to Fe-P forms, but the majority of the $\mathrm{P}(63 \%)$ was still present in adsorbed forms (Table 3). A possible reason for these trends with placement maybe attributed to the $\mathrm{pH}$ differences (Fig. 1a and 1b). Deepbanded liquid $\mathrm{P}$ had soil $\mathrm{pH}$ of $\sim 4.8$, whereas broadcast liquid $\mathrm{P}$ had soil $\mathrm{pH}$ of $\sim 5.1$. Low $\mathrm{pH}$ might have resulted more soluble $\mathrm{Fe}$ in soil solution, thus promoting $\mathrm{Fe}-\mathrm{P}$ formation as opposed to Ca-associated P.

Comparison of resin-extractable $\mathrm{P}$ data with speciation results showed a positive correlation of adsorbed $\mathrm{P}$ species with resin-extractable $\mathrm{P}$, suggesting that adsorbed $\mathrm{P}$ species might be more available. For liquid $\mathrm{P}$ treatments with higher resinextractable $\mathrm{P}$, the dominant $\mathrm{P}$ species were found in adsorbed P-like forms. The liquid MAP likely appeared to be in more "accessible" forms than the granular MAP due to the differences in diffusion of $\mathrm{P}$ from granular and liquid MAP. Lombi et al. (2006) found that liquid MAP remained in potentially plantavailable form (as measured by isotopically exchangeable $\mathrm{P}$ ) because of increased diffusion compared with the granular MAP in a highly calcareous soil. The limited diffusion of $\mathrm{P}$ from granular MAP is suggested to be because of mass flow of water toward the highly hygroscopic granule moving against the direction of dissolved P diffusion (Lawton and Vomocil, 1954; Hettiarachchi et al., 2006). Similarly, the current study shows that liquid MAP tended to form relatively more adsorbed-P forms and less Fephosphate-like $\mathrm{P}$ than the granular MAP treatment in this acid soil.

\section{Time Effect}

At $6 \mathrm{mo}$ in the urea broadcast treatment (broadcast $+\mathrm{N}$ control), a greater portion of $\mathrm{P}$ was found to be in adsorbed-P forms (82.6\%), whereas in the added urea deepband treatment (broadcast $+\mathrm{N}$ control), $\mathrm{P}$ transformed to more $\mathrm{Ca}-\mathrm{P}$ like forms $(83.4 \%)$ over time. The increase in $\mathrm{pH}$ over time might have favored formation of more adsorbed- or Ca-P-like forms compared with their 5-wk samples (after perturbation of the system by adding urea). For MAP added treatments, with time $\mathrm{P}$ reaction products changed from more $\mathrm{Fe}-\mathrm{P}$-like forms to $\mathrm{Ca}-\mathrm{P}$ forms ( 5 and $24 \%$ of $\mathrm{Ca}-\mathrm{P}$ at $5 \mathrm{wk}$ increased to 66 and 39\% at 6 mo for MAP broadcast and MAP deep-band treatments, respectively). In both liquid MAP broadcast and deep-band treatments, $\mathrm{P}$ continued to be in more adsorbed P-like forms (79.2 and 80.2\%, respectively) (Table 4).

The surface soil had relatively lower resin-extractable $\mathrm{P}$ (25 $\mathrm{mg} \mathrm{kg}^{-1}$ for MAP and $32.65 \mathrm{mg} \mathrm{kg}^{-1}$ for TGMAP) (Fig. 3) compared with deeper $(7-15 \mathrm{~cm})$ soil $\left(52.45 \mathrm{mg} \mathrm{kg}^{-1}\right.$ for MAP and $85.38 \mathrm{mg} \mathrm{kg}^{-1}$ for TGMAP). Consequently, the relative differences in reaction products in broadcast and deep-band treatments over time might be related to resin-extractable P levels at given time periods. Soils layered with higher resin-extractable $\mathrm{P}$ after $\mathrm{P}$ application showed relatively more soluble species of $\mathrm{P}$ compared with soil layers with low resin-extractable P. Lindsay (1979) suggested the formation of sparingly soluble mixed Alphosphates and/or Fe-phosphates as a possible mechanism that restricts $\mathrm{P}$ solubility in acid soils. Calcium phosphates such as apatite are the stable $\mathrm{P}$ species formed in alkaline soil through time after P fertilizer applications (Lindsay, 1979). Similarly, depending on the activity of $\mathrm{Ca}^{2+}$ in soil solutions, precipitation of $\mathrm{P}$ as Ca-phosphates also can be responsible for restricting $\mathrm{P}$ solubility in slightly acid, neutral, and alkaline soils.

Anions such as phosphate can bind strongly to the mineral surfaces of $\mathrm{Fe}$ and $\mathrm{Al}$ oxides, particularly at lower $\mathrm{pH}$ values (Hingston et al., 1967, 1968). Adsorbed P was prominent in a majority of the treatments, especially where liquid MAP was added. The Fe-P forms were also present in granular P treatments after $5 \mathrm{wk}$. The standards included in our study were $\mathrm{P}$ adsorbed on ferrihydrite, goethite, alumina, and gibbsite, each of which displays complex behavior with $\mathrm{P}$ in pure mineral systems (Arai and Sparks, 2007); thus, teasing out the exact nature of

Table 4. Phosphorus K- X-ray absorption near edge structure (XANES) fitting results for 6-mo samples performed in normalized space with an energy range from 2144 to $2179 \mathrm{eV}$ showing the relative proportion of phosphate minerals showing best fit.

\begin{tabular}{|c|c|c|c|c|c|}
\hline Treatment & Ca-P minerals & Al-P minerals & Fe-P minerals & Adsorbed P & Red. $\chi 2+$ \\
\hline Control broadcast & - & - & 32.0 & 68.0 & 0.010 \\
\hline Urea broadcast & - & - & 17.4 & 82.6 & 0.031 \\
\hline MAP broadcast ‡ & 66.2 & - & 5.1 & 28.7 & 0.013 \\
\hline TGMAP broadcast $\ddagger$ & 20.8 & - & - & 79.2 & 0.015 \\
\hline Control deep-band & 6.4 & 39.7 & 53.9 & - & 0.098 \\
\hline Urea deep-band & 83.4 & - & 16.6 & - & 0.214 \\
\hline MAP deep-band & 38.5 & - & 7.6 & 53.9 & 0.009 \\
\hline TGMAP deep-band & 19.8 & - & - & 80.2 & 0.010 \\
\hline \multicolumn{6}{|c|}{$\begin{array}{l}\chi \chi^{2}=\Sigma(\text { fit- data) } / \varepsilon]^{2} /\left(\mathrm{N}_{\text {data }}-\mathrm{N}_{\text {components }}\right) \text { is the reduced chi-square statistic. Here, } \varepsilon \text { is the estimate } \\
\text { uncertainty in the normalized XANES data (taken as } 0.01 \text { for all data). The sum is over } \mathrm{N}_{\text {data }} \text { points ( } 18 \\
\text { data points between } \mathrm{E}=2144 \text { and } 2179 \mathrm{eV} \text { for all data), and } \mathrm{N}_{\text {components }} \text { is the number of component } \\
\text { in the fit (either } 2 \text { or } 3 \text { as indicated in the Table). The total percentage was constrained to be } 100 \% \text { in a } \\
\text { fits. Typical uncertainties in the percentages listed for each standard component are } 5 \% \text {. }\end{array}$} \\
\hline
\end{tabular}


the adsorbed $\mathrm{P}$ complex is difficult. Moreover, adsorption and precipitation of $\mathrm{P}$ are known to occur on a continuum (Arai and Sparks, 2007).

Notably, a portion of $\mathrm{P}$ is associated with $\mathrm{Ca}$ in liquid MAP broadcast treatment despite the low soil $\mathrm{pH}$ conditions (Table 3 and Fig. 1). Co-existence of adsorbed $\mathrm{P}$ and $\mathrm{Ca}-\mathrm{P}$ forms is not uncommon in acidic soils. Previous $\mathrm{P}$ K-edge XANES results indicated that $\mathrm{P}$ was adsorbed on $\mathrm{Fe}$ and $\mathrm{Al}$ oxides as well as $\mathrm{Ca}-\mathrm{P}$ forms in acidic soils (Beauchemin et al., 2003). Using chemical extractions, Simard et al. (1995) found co-existence of Ca-P forms, assessed by $\mathrm{HCl}$ extractions, and $\mathrm{Fe} / \mathrm{Al}-\mathrm{P}$, evaluated by $\mathrm{NaOH}$ extraction. After 6 mo, there was a negligible change in distribution of $\mathrm{P}$ in liquid MAP treatments, but granular MAP broadcast treatments increased in the proportion of $\mathrm{Ca}-\mathrm{P}$ forms to $66 \%$. The soil $\mathrm{pH}$ values increased with time (Fig. 1) and could have promoted conditions for $\mathrm{Ca}-\mathrm{P}$ precipitation to occur (Lindsay, 1979). Soil in the current study had higher extractable Ca concentration than extractable $\mathrm{Al}$ and $\mathrm{Fe}$ (Table 1). Adsorption interactions between $\mathrm{Ca}$ and $\mathrm{P}$ also might be in operation, because these interactions have been reported in pure mineral systems (Helyar et al., 1976; Rietra et al., 2001). These results underscore the complexity of $\mathrm{P}$ speciation in heterogeneous soil samples.

\section{CONCLUSIONS}

When liquid MAP is deep-banded in a reduced-till soil system, more $\mathrm{P}$ appears to remain in resin-extractable $\mathrm{P}$ forms for 6 mo after fertilizer application. In contrast, broadcast $P$, either in granular or in liquid form, tended to transform into less extractable $P$ forms after $5 \mathrm{wk}$ to 6 mo. Speciation results showed that granular P fertilizers tended to form Fe P-like products, whereas liquid forms were found to remain in adsorbed P-like forms in soil after 5 wk of application. When comparing deepband granular MAP treatment to broadcast granular MAP treatment, speciation results showed a reduction in precipitated $P$ forms and higher resin-extractable $P$ in the deep-band granular MAP treatments compared with the broadcast granular MAP treatments at $5 \mathrm{wk}$, thus proving our second hypothesis that deep-banding would result in lower precipitated forms of $P$ than broadcast placements. In a 6 -mo period, reaction products of broadcast granular and broadcast liquid and deep-band granular fertilizers transformed to Ca-phosphate or mixtures of Ca-, $\mathrm{Fe}-$, and adsorbed-phosphate-like forms, whereas deep-band liquid $\mathrm{P}$ continued to remain mainly as adsorbed P-like forms. Formation of $\mathrm{Fe}$ - and/or $\mathrm{Ca}-\mathrm{P}$ solid species, known to have different solubilities, may have been the reason for the observed differences in resin extractability or potential availability of $\mathrm{P}$ between broadcast and deep-banded granular and liquid MAP evaluated in this study. Spectroscopic investigations appeared to agree with resin-extractable $P$ results and suggest that when liquid or granular $\mathrm{P}$ is deep-banded, more $\mathrm{P}$ remains in comparatively more soluble forms of $\mathrm{P}$ in soil, whereas surface-applied granular and liquid $\mathrm{P}$ tend to transform into comparatively less soluble $\mathrm{P}$ forms in $6 \mathrm{mo}$.

\section{ACKNOWLEDGMENTS}

We would like to thank Kansas State University Phosphorus Fellowship Consortium of International Plant Nutrition Institute; Mosaic, Agrium, Potash Corp.; and JR Simplot for funding the project. Data were collected at the X-ray Operations and Research beamline 9-BM-B at the Advanced Photon Source, Argonne National Laboratory. Thanks to Trudy Bolin at the sector 9 for X-ray data collection and useful suggestions. Use of the Advanced Photon Source, an Office of Science User Facility operated for the U.S. Department of Energy (DOE) Office of Science by Argonne National Laboratory, was supported by the U.S. DOE under Contract no. DE-AC02$06 \mathrm{CH} 11357$. We acknowledge the well considered and constructive review comments made by three anonymous reviewers and the associate editor. We would like to acknowledge the editorial assistance provided by Sarah Caldwell-Hancock at K-State Research and Extension. This is contribution no.12-066-J from the Kansas Agricultural Experiment Station.

\section{REFERENCES}

Arai, Y., and D.L. Sparks. 2007. Phosphate reaction dynamics in soils and soil components: A multiscale approach. Adv. Agron. 94:135-179. doi:10.1016/S0065-2113(06)94003-6

Beauchemin, S., D. Hesterberg, J. Chou, M. Beauchemin, R.R. Simard, and D.E. Sayers. 2003. Speciation of phosphorus in phosphorus-enriched agricultural soils using X-ray absorption near-edge structure spectroscopy and chemical fractionation. J. Environ. Qual. 32:1809-1819. doi:10.2134/jeq2003.1809

Benbi, D.K., and R.J. Gilkes. 1987. The movement into soil of P from superphosphate grains and its availability to plants. Fert. Res. 12:21-36. doi:10.1007/BF01049418

Bordoli, J.M., and A.P. Mallarino. 1998. Deep and shallow banding of phosphorus and potassium as alternatives to broadcast fertilization for no-till corn. Agron. J. 90:27-33. doi:10.2134/agronj1998.00021962009000010006x

Bray, R.H., and L.T. Kurtz. 1945. Determination of total, organic, and available forms of phosphorus is soils. Soil Sci. 59:39-45. doi:10.1097/00010694194501000-00006

Bremner, J.M., and C.S. Mulvaney. 1982. Salicylic acid thiosulfate modification of the Kjeldhal method to include nitrate and nitrite. In: R.H. Miller and D.R. Keeney, editors, Methods of soil analysis. Part 2. ASA, Madison, WI. p. 621

Chapman, H.D. 1965. Cation exchange capacity. In: C.A. Black, editor, Methods of soil analysis. Agron. Monogr. 9. ASA, Madison, WI. p. 891-901.

Combs, S.M., and M.V. Nathan. 1998. Soil organic matter. In: J.R. Brown, editor, Recommended chemical soil test procedures for the North Central Region. NCR Publ. no. 221. Missouri Agric. Exp. Stn., Columbia. p. 53-58.

Dalas, E. 1991. The crystallization of ferric phosphate on cellulose. J. Cryst. Growth 113:140-146. doi:10.1016/0022-0248(91)90019-2

Fixen,P.E., and A.E.Ludwick. 1982. Residual available phosphorus in near-neutral and alkaline soils: II, Perspective and quantitative estimation. Soil Sci. Soc. Am. J. 46:335-338. doi:10.2136/sssaj1982.03615995004600020025x

Foth, H.D., and B.G. Ellis. 1997. Soil fertility. CRC Press, Boca Raton, FL.

Frank, K., D. Beegle, and J. Denning. 1998. Phosphorus. In: J.R. Brown, editor, Recommended chemical soil test procedures for the North Central Region. NCR Publ. no. 221. Missouri Agric. Exp. Stn., Columbia. p. 21-23.

Hansen, N.C., T.C. Daniel, A.N. Sharpley, and J.L. Lemunyon. 2002. The fate and transport of phosphorus in agricultural systems. J. Soil Water Conserv. $57: 408-417$.

Hanson, R.L., and D.G. Westfall. 1985. Orthophosphate solubility and availability from dual applied nitrogen and phosphorus. Soil Sci. Soc. Am. J. 49:1283-1289. doi:10.2136/sssaj1985.03615995004900050043x

Hedley, M., and M. McLaughlin. 2005. Reactions of phosphate fertilizers and by-products in soils. In: J.T. Sims and A. Sharpley, editors, Phosphorus: Agriculture and the environment. Agron. Monogr. 46. ASA, CSSA, and SSSA, Madison, WI. p. 181-252.

Helyar, K.R., D.N. Munns, and R.G. Burau. 1976. Adsorption of phosphate by gibbsite. I. Effects of neutral chloride salts of calcium, magnesium, sodium, and potassium. J. Soil Sci. 27:307-314. doi:10.1111/j.1365-2389.1976.tb02001.x

Hesterberg, D., W.Q. Zhou, K.J. Hutchison, S. Beauchemin, and D.E. Sayers. 1999. XAFS study of adsorbed and mineral forms of phosphate. J. Synchrotron Radiat. 6:636-638. doi:10.1107/S0909049599000370

Hettiarachchi, G.M., E. Lombi, M.J. McLaughlin, D. Chittleborough, and P. Self. 2006. Density changes around phosphorus granules and fluid bands in a 
calcareous soil. Soil Sci. Soc. Am. J.70:960-966. doi:10.2136/sssaj2005.0296

Hingston, F.J., R.J. Atkinson, A.M. Posner, and J.P. Quirk. 1967. Specific adsorption of anions. Nature (London) 215:1459-1461. doi: $10.1038 / 2151459 \mathrm{a} 0$

Hingston, F.J., R.J. Atkinson, A.M. Posner, and J.P. Quirk. 1968. Specific adsorption of anions on goethite. Transactions of the 9th International Congress on Soil Science, Adelaide, SA. Vol. 1. Int. Soil Sci. Soc. and Angus and Robertson, Sydney. p. 669-678.

Hobbs, P.R., K. Sayre, and R. Gupta. 2008. The role of conservation agriculture in sustainable agriculture. Philos. Trans. R. Soc. B-Biol. Sci. 363:543-555.

Holloway, R.E., I. Bertrand, A.J. Frischke, D.M. Brace, M.J. McLaughlin, and W. Shepperd. 2001. Improving fertiliser efficiency on calcareous and alkaline soils with fluid sources of P, N and Zn. Plant Soil 236:209-219. doi:10.1023/A:1012720909293

Hsu, P.H., and F. Sikora. 1993. Effects of aluminum and phosphate concentrations and acidity on the crystallization of variscite at 90-degrees-C. Soil Sci. 156:71-78. doi:10.1097/00010694-199308000-00002

Khare, N., D. Hesterberg, and J.D. Martin. 2005. XANES investigation of phosphate sorption in single and binary systems of iron and aluminum oxide minerals. Environ. Sci. Technol. 39:2152-2160. doi:10.1021/es049237b

Kilmer, V.J., and L.T. Alexander. 1949. Methods of making chemical analyses of soils. Soil Sci. 68:15-24. doi:10.1097/00010694-194907000-00003

Lawton, K., and J.A. Vomocil. 1954. The dissolution and migration of phosphorus from granular superphosphate in some Michigan soils. Soil Sci. Soc. Am. Proc. 18:26-32. doi:10.2136/sssaj1954.03615995001800010008x

Lindsay, W.L. 1979. Chemical equilibria in soils. Wiley-Interscience, New York.

Lombi, E., M.J. McLaughlin, C. Johnston, R.D. Armstrong, and R.E. Holloway. 2004. Mobility and lability of phosphorus from granular and fluid monoammonium phosphate differs in a calcareous soil. Soil Sci. Soc. Am. J. 68:682-689. doi:10.2136/sssaj2004.0682

Lombi, E., K.G. Scheckel, R.D. Armstrong, S. Forrester, J.N. Cutler, and D. Paterson. 2006. Speciation and distribution of phosphorus in a fertilized soil: A synchrotron-based investigation. Soil Sci. Soc. Am. J. 70:20382048. doi:10.2136/sssaj2006.0051

Malinowski, E.R. 1991. Factor analysis in chemistry. 2nd ed. John Wiley \& Sons, New York.

Mallarino, A.P., and A.M. Atia. 2005. Correlation of a resin membrane soil phosphorus test with corn yield and routine soil tests. Soil Sci. Soc. Am. J. 69:266-272. doi:10.2136/sssaj2005.0266

Marcus, M.A., A.A. MacDowell, R. Celestre, A. Manceau, T. Miller, H.A. Padmore, and R.E. Sublett. 2004. Beamline 10.3.2 at ALS: A hard X-ray microprobe for environmental and materials sciences. J. Synchrotron Radiat. 11:239-247. doi:10.1107/S0909049504005837

McBeath, T.M., R.D. Armstrong, E. Lombi, M.J. McLaughlin, and R.E. Holloway. 2005. Responsiveness of wheat (Triticum aestivum L) to liquid and granular phosphorus fertilizers in southern Australian soils. Aust. J. Soil Res. 43:203-212. doi:10.1071/SR04066

McLean, E.O. 1965. Aluminum. In: C.A. Black, editor, Methods of soil analysis. Agron. Monogr. 9. ASA, Madison, WI. p. 990-992.

Mehlich, A. 1984. Mehlich 3 soil test extractant: A modification of the Mehlich 2 extractant. Commun. Soil Sci. Plant Anal. 15:1409-1416. doi: $10.1080 / 00103628409367568$

Menon, R.G., S.H. Chien, and L.L. Hammond. 1990. Development and evaluation of the Pi soil test for plant-available phosphorus. Commun. Soil Sci. Plant Anal. 21:1131-1150. doi:10.1080/00103629009368295

Moody, P.W., D.G. Edwards, and L.C. Bell. 1995. Effect of banded fertilizers on soil solution composition and short-term root growth:II. Mono and di-ammonium phosphates. Aust. J. Soil Res. 33:689-707. doi:10.1071/SR9950689

Murphy, J., and J.P. Riley. 1962. A modified single solution method for the determination of phosphate in natural waters. Anal. Chim. Acta 27:31-36. doi:10.1016/S0003-2670(00)88444-5

Myers, R.G., A.N. Sharpley, S.J. Thien, and G.M. Pierzynski. 2005. Ion-sink phosphorus extraction methods applied on 24 soils from the continental USA. Soil Sci. Soc. Am. J. 69:511-521. doi:10.2136/sssaj2005.0511

Nachtegaal, M., M.A. Marcus, J.E. Sonke, J. Vangronsveld, K.J.T. Livi, D. van Der Lelie, and D.L. Sparks. 2005. Effects of in situ remediation on the speciation and bioavailability of zinc in a smelter contaminated soil. Geochim. Cosmochim. Acta 69:4649-4664. doi:10.1016/j.gca.2005.05.019

Oh, Y.M., D. Hesterberg, and P.V. Nelson. 1999. Phosphate adsorption on clay minerals as a pre-plantsource of phosphorus in soilless root media. Commun. Soil Sci. Plant Anal. 30:747-756. doi:10.1080/00103629909370243

Peak, D., J.T. Sims, and D.L. Sparks. 2002. Solid-state speciation of natural and alum-amended poultry litter using XANES spectroscopy. Environ. Sci. Technol. 36:4253-4261. doi:10.1021/es025660d

Pierzynski, G.M., T.J. Logan, S.J. Traina, and J.M. Bingham. 1990. Phosphorus chemistry and mineralogy in excessively fertilized soils: Quantitative analysis of phosphorus-rich particles. Soil Sci. Soc. Am. J. 54:1576-1583. doi:10.2136/sssaj1990.03615995005400060011x

Pierzynski, G.M., J.T. Sims, and G.F. Vance. 2000. Soils and environmental quality. 2nd ed. CRC Press, Boca Raton, FL.

Ravel, B., and M. Newville. 2005. ATHENA, ARTEMIS, HEPHAESTUS: Data analysis for X-ray absorption spectroscopy using IFEFFIT. J. Synchrotron Radiat. 12:537-541. doi:10.1107/S0909049505012719

Rietra, R.P., T. Hiemstra, and W.H. van Riemsdijk. 2001. Interaction between calcium and phosphate adsorption on goethite. Environ. Sci. Technol. 35:3369-3374. doi:10.1021/es000210b

Saggar, S., M.J. Hedley, and R.E. White. 1990. A simplified resin membrane technique for extracting phosphorus from soils. Fert. Res. 24:173-180. doi:10.1007/BF01073586

Salcedo, I.H., F. Bertino, and E.V.S.B. Sampaio. 1991. Reactivity of phosphorus in Northeastern Brazilian soils assessed by isotopic dilution. Soil Sci. Soc. Am. J. 55:140-145. doi:10.2136/sssaj1991.03615995005500010025x

SAS Institute. 2007. The SAS system for windows version 9.1.3. SAS Institute, Cary, NC.

Sato, S., D. Solomon, C. Hyland, Q.M. Ketterings, and J.Lehmann. 2005. Phosphorus speciation in manure and manure-amended soils using XANES spectroscopy. Environ. Sci. Technol. 39:7485-7491. doi:10.1021/es0503130

Schwab, G.J., D.A. Whitney, G.L. Kilgore, and D.W. Sweeney. 2006. Tillage and phosphorus management effects on crop production in soils with phosphorus stratification. Agron. J. 98:430-435. doi:10.2134/agronj2005.0050

Schwertmann, U., and R.M. Cornell. 1991. Iron oxides in the laboratory: Preparation and characterization. VCH Publ. Co., Weinheim, Germany.

Sharpley, A.N. 1991. Soil phosphorus extracted by iron-aluminum-oxideimpregnated filter paper. Soil Sci. Soc. Am. J. 55:1038-1041. doi:10.2136/ sssaj1991.03615995005500040025x

Sharpley, A.N., J.T. Sims, and G.M. Pierzynski. 1994. Innovative soil phosphorus indices: Assessing inorganic phosphorus. In: J. Havlin and J.S. Jacobsen, editors, Soil testing: Prospects of improving nutrient recommendations. SSSA Spec. Publ. 40. SSSA and ASA, Madison, WI. p. 115-142.

Simard, R.R., D. Cluis, G. Gangbazo, and S. Beauchemin. 1995. Phosphorus status of forest and agricultural soils from a watershed of high animal density. J. Environ. Qual. 24:1010-1017. doi:10.2134/ jeq1995.00472425002400050033x

Sims, J.T., A.C. Edwards, O.F. Schoumans, and R.R. Simard. 2000. Integrating soil phosphorustestingintoenvironmentallybasedagricultural managementpractices. J. Environ. Qual. 29:60-71. doi:10.2134/jeq2000.00472425002900010008x

Soil Survey Laboratory Staff. 2004. Soil survey laboratory methods manual. Soil Survey Investigations Rep. no. 42 version 4.0. Natl. Soil Survey Ctr., Lincoln, NE.

Sposito, G. 1989. The chemistry of soils. Oxford Univ. Press, New York.

Thomas, G.W. 1996. Soil pH and soil acidity. In: Methods of soil analysis. Part 3. Chemical methods. SSSA, Madison, WI. p. 475-490.

Toor, G.S., S. Hunger, J.D. Peak, J.T. Sims, and D.L. Sparks. 2006. Advances in the characterization of phosphorus in organic wastes: Environmental and agronomic applications. Adv. Agron. 89:1-72. doi:10.1016/S0065-2113(05)89001-7

Warncke, D.M., and J.R. Brown. 1998. Potassium and other basic cations. In: J.R. Brown, editor, Recommended chemical soil test procedures for the North Central Region. NCR Publ. no. 221. Missouri Agric. Exp. Stn., Columbia. p. 31-33.

Watanabe,F.S., and S.R.Olsen. 1965. Test of an ascorbicacid method for determining phosphorus in water and $\mathrm{NaHCO}_{3}$ extracts from soils. Soil Sci. Soc. Am. Proc. 29:677-678. doi:10.2136/sssaj1965.03615995002900060025x

Wateson, M.E., and J.R. Brown. 1998. pH and lime requirement. In: J.R. Brown, editor, Recommended chemical soil test procedures for the North Central Region. NCR Publ. no. 221. Missouri Agric. Exp. Stn., Columbia. p. 13-16.

Whitney, D.A. 1998. Soil salinity. In: J.R. Brown, editor, Recommended chemical soil test procedures for the North Central Region. NCR Publ. no. 221. Missouri Agric. Exp. Stn., Columbia. p. 59-60. 